\title{
Un moulin hydraulique horizontal au Liban : L'exemple du Yunin (la beqa')
}

\section{Aïda Kanafani-Zahar}

\section{(2) OpenEdition}

1 Journals

Édition électronique

URL : https://journals.openedition.org/tc/744

DOI : $10.4000 /$ tc. 744

ISSN : 1952-420X

Éditeur

Éditions de l'EHESS

\section{Édition imprimée}

Date de publication : 1 septembre 1991

ISSN : 0248-6016

\section{Référence électronique}

Aïda Kanafani-Zahar, « Un moulin hydraulique horizontal au Liban : L'exemple du Yunin (la beqa')», Techniques \& Culture [En ligne], 15 | 1991, mis en ligne le 12 janvier 2006, consulté le 29 septembre 2022. URL : http://journals.openedition.org/tc/744 ; DOI : https://doi.org/10.4000/tc.744

Ce document a été généré automatiquement le 29 septembre 2022.

Tous droits réservés 


\section{Un moulin hydraulique horizontal au Liban : L'exemple du Yunin (la beqa')}

Aïda Kanafani-Zahar 